\title{
A NEW SPECIES OF PSEUDOTEPHRITIS.
}

\author{
By Charles W. Johnson, \\ Boston Society of Natural History.
}

Pseudotephritis metzi sp. nov.

Female: Front yellowish pollinose, thickly dispersed with fine black punctures each bearing a small hair, vertex grayish with two orbital and two ocellar bristles, a large round spot on the occiput back of the ocelli with two bristles, and two small dots on each side also bearing bristles, occipital orbits with a row of seven bristle bearing dots, the two lower ones slightly removed from the others; face yellowish pollinose with numerous fine hairs; palpi and antennæ yellow, the third joint brown. Thorax grayish pollinose thickly punctured with black, each puncture bearing a minute hair, dorsum with eight large spots arranged alternately in four rows. In front of the scutellum is a short black line with two bristle bearing dots on each side, above the wing and on the pleura are large irregular spots; scutellum with two large shining discal spots, and four marginal bristle bearing dots, under side of the scutellum with two large black spots with a yellowish band below; metanotum grayish above, shining black below. Abdomen grayish pollinose, finely punctated with black and with short fine black hairs; first segment subshining, third with two large black quadrate spots on the anterior margin and two oblong spots on the posterior margin, the latter narrowly separated by a dorsal line; fourth with similar markings but closer together and occupying the middle third of the segment, first segment of the ovipositor broad, truncated at the end, slightly pollinose and shining. Legs: femora except the tips and a sub-basal and subapical band on the tibiæ, brownish black, the remainder yellowish. Halteres white. Wings hyaline, with blackish markings arranged as follows-a slight clouding at the humeral cross-vein and across the base of the basal cells; a large spot or band commences near the end of the first costal cell extending across the second, the marginal, base of the submarginal and middle of the first basal cell; another large spot starts near the middle of the discal and extends across the third posterior cell to near the end of the sixth longitudinal vein. There is also a small spot at the base of the third posterior cell, a small spot at the end of the auxilliary vein, a large spot at the end of second costal cell extending irregularly to and slightly beyond the anterior cross-vein, a large spot halfway between the ends of the first and second longitudinal veins, a spot on the posterior cross-vein and an apical band extending from the tip of the marginal to the tip of the second posterior cells. Length $7 \mathrm{~mm}$. Wing $6 \mathrm{~mm}$.

One specimen. Cold Spring Harbor, Long Island, N. Y. Collected by Mr. C. W. Metz.

The species resembles $P$. vau Say., in the arrangement of the costal spots but the spots are not connected with those of the posterior margin by large yellowish cloudings. The apical spot is larger than in $P$. vau. 

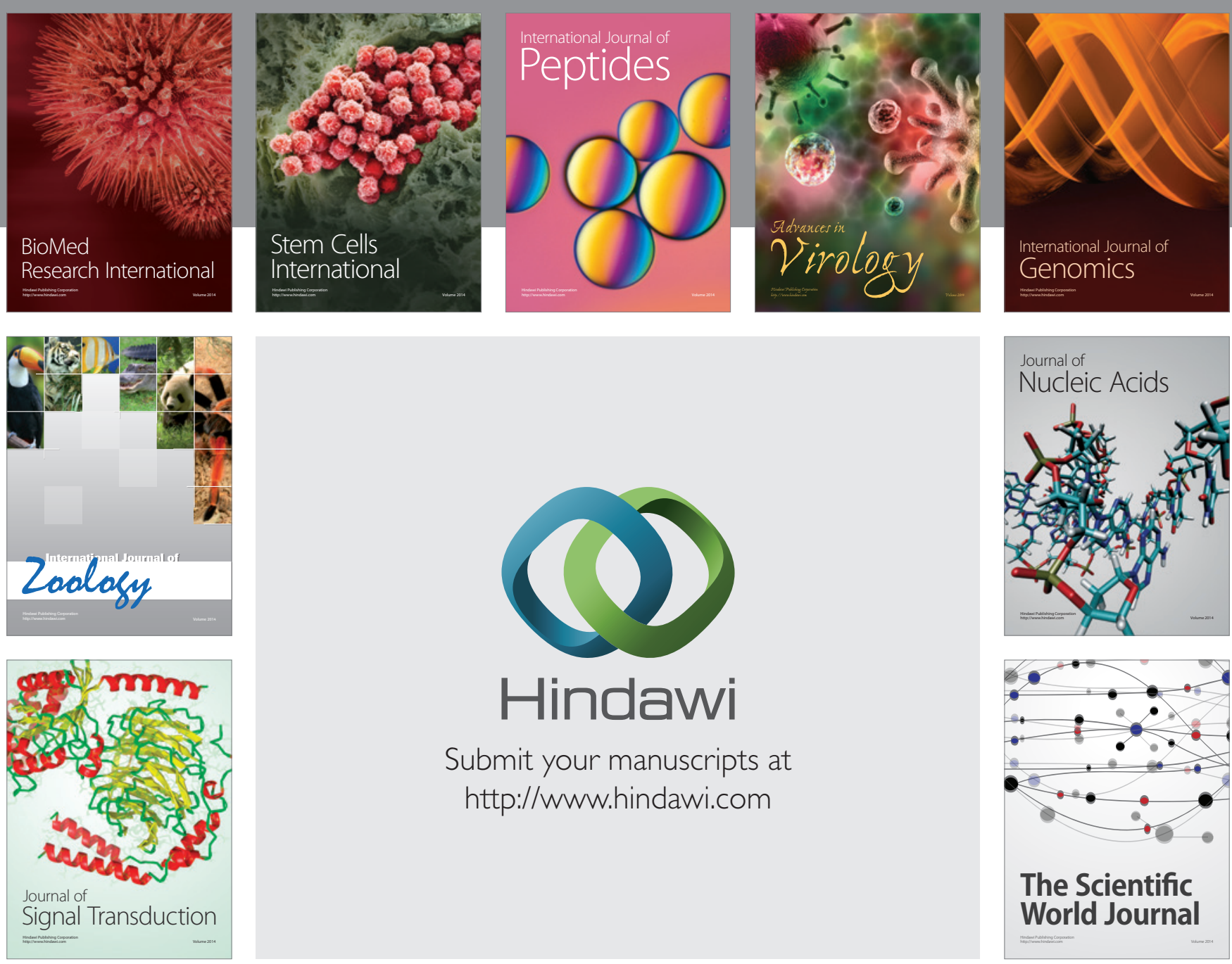

Submit your manuscripts at

http://www.hindawi.com
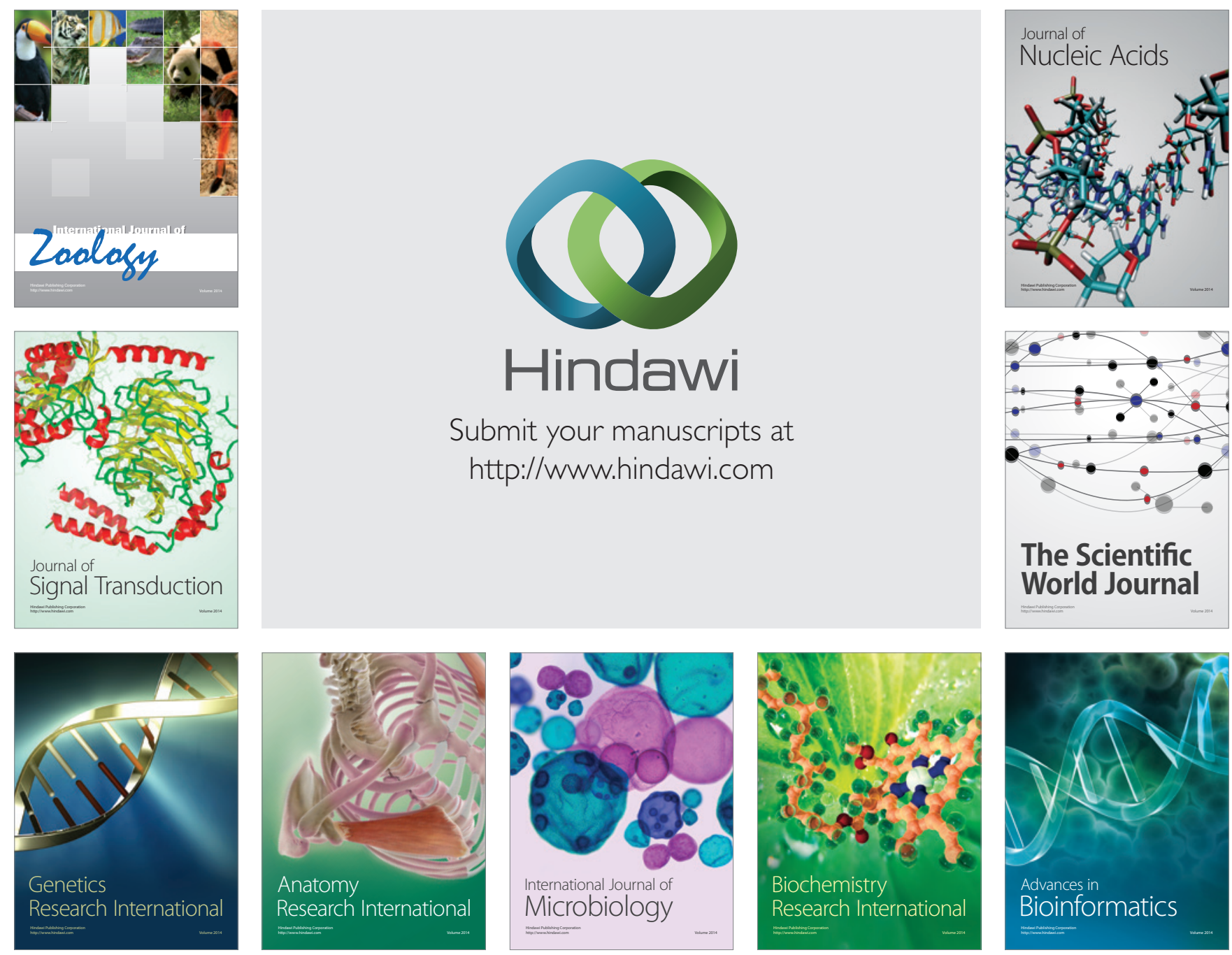

The Scientific World Journal
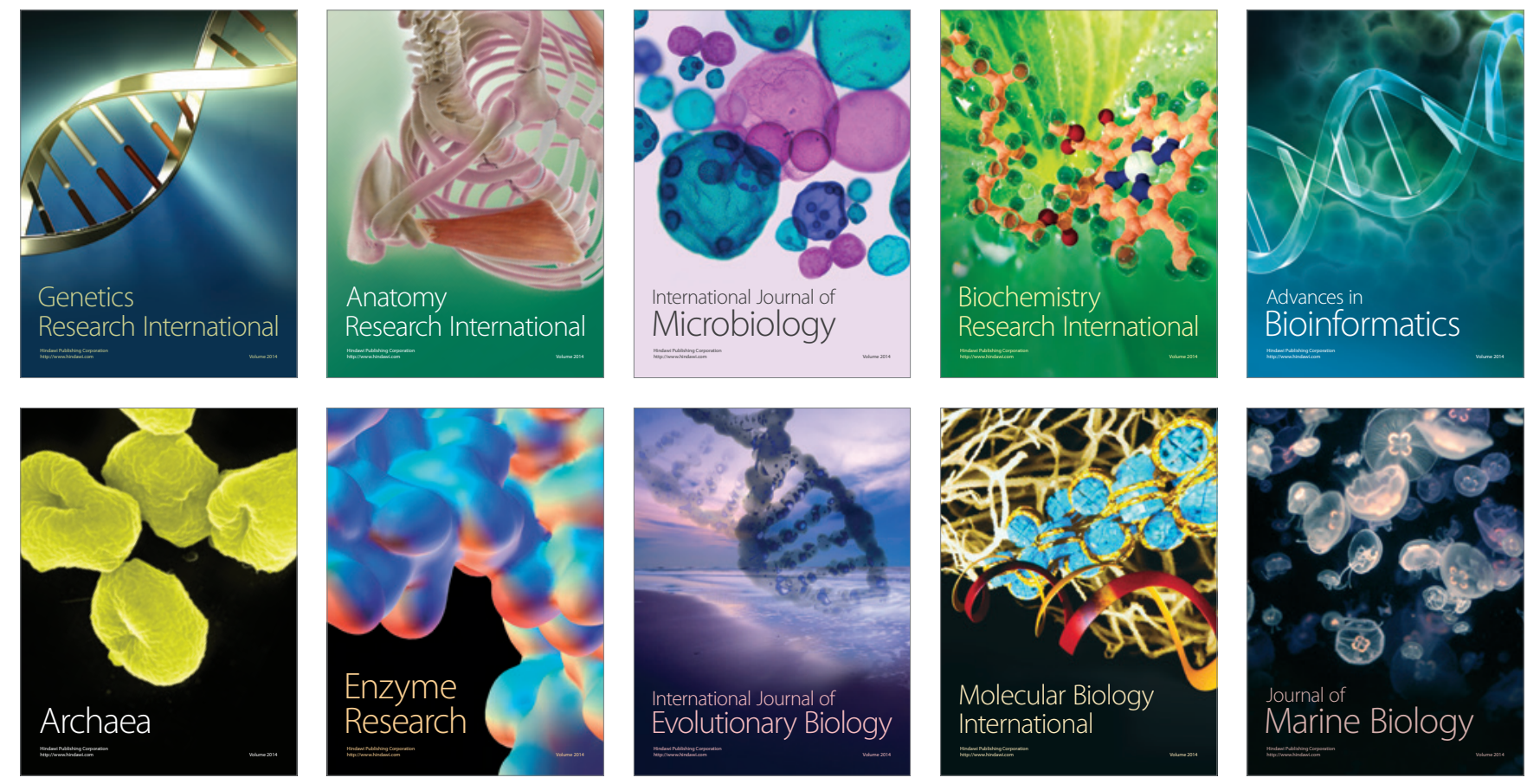